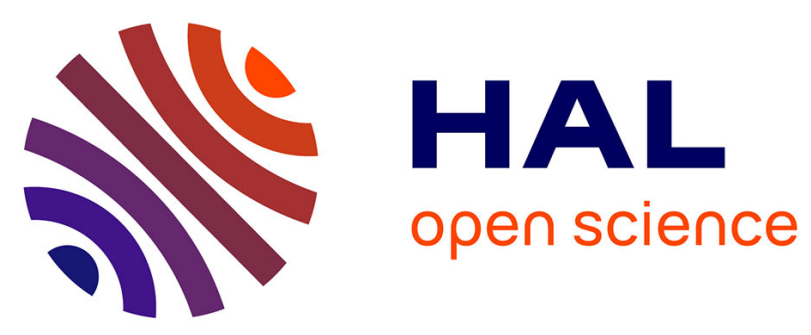

\title{
The Free Oxygen Radicals Test (FORT) to assess circulating oxidative stress in patients with acute myocardial infarction
}

L. Lorgis, M. Zeller, G. Dentan, P. Sicard, C. Richard, P. Buffet, I. L'huillier, J.C. Beer, Y. Cottin, L. Rochette, et al.

\section{To cite this version:}

L. Lorgis, M. Zeller, G. Dentan, P. Sicard, C. Richard, et al.. The Free Oxygen Radicals Test (FORT) to assess circulating oxidative stress in patients with acute myocardial infarction. Atherosclerosis, 2010, 213 (2), pp.616-621. 10.1016/j.atherosclerosis.2010.09.018 . hal-03435467

\section{HAL Id: hal-03435467 \\ https://u-bourgogne.hal.science/hal-03435467}

Submitted on 18 Nov 2021

HAL is a multi-disciplinary open access archive for the deposit and dissemination of scientific research documents, whether they are published or not. The documents may come from teaching and research institutions in France or abroad, or from public or private research centers.
L'archive ouverte pluridisciplinaire HAL, est destinée au dépôt et à la diffusion de documents scientifiques de niveau recherche, publiés ou non, émanant des établissements d'enseignement et de recherche français ou étrangers, des laboratoires publics ou privés. 
The Free Oxygen Radicals Test (FORT) to assess circulating oxidative stress in patients with acute myocardial infarction

Lorgis $\mathrm{L}^{1}$, MD, PhD, Zeller $\mathrm{M}^{2}$, PhD, Dentan $\mathrm{G}^{3}$,MD, Sicard $\mathbf{P}^{2}$, PhD, Buffet $\mathbf{P}^{1}$, MD, L'Huillier I', MD, Beer JC' ${ }^{1}$, MD, Cottin $Y^{1}$, MD, PhD, Rochette $\mathbf{L}^{2}$, PharmD, PhD, Vergely $\mathrm{C}^{2}$, PharmD, PhD, on behalf of the RICO survey working group

${ }^{1}$ Department of Cardiology, University Hospital, Dijon, France; ${ }^{2}$ Laboratory of Experimental Cardiovascular Pathophysiology and Pharmacology, IFR santé STIC, University of Burgundy, Dijon, France; ${ }^{3}$ Department of Cardiology, Clinique de Fontaine, Fontaine les Dijon, France.

Address for correspondence: Luc LORGIS, Service de Cardiologie,

CHU Dijon, Bd de Lattre de Tassigny, 21034 Dijon Cedex, France.

Tel: (33) $380293311 \quad$ Fax: (33) 380293333

E-mail: luc.lorgis@chu-dijon.fr

Disclosures: The authors have no potential conflicts of interest to disclose in connection with the submitted article.

Funding: This work was supported by the University Hospital of Dijon, the Association de Cardiologie de Bourgogne, and by grants from the Union Régionale des Caisses d'Assurance Maladie de Bourgogne (URCAM), the Agence Regionale d'Hospitalisation (ARH) de Bourgogne, the Conseil Régional de Bourgogne and the Fédération Française de Cardiologie (FFC).

Total word count: 4449

Brief title: Reactive oxygen species, FORT, myocardial infarction. 


\section{ABSTRACT}

Background and aim: Reactive oxygen species (ROS) play an important role in the pathogenesis of many diseases including cardiovascular diseases. Several methods have been developed for the direct or indirect measurement of oxygen free radical and its by-products. The current study was designed to validate the new Free Oxygen Radicals Test (FORT) and to investigate the potential relationships between ROS and clinical or biological factors in male patients with acute myocardial infarction (AMI).

Methods: We analysed FORT values in samples from 66 patients with AMI.

Results: FORT values ranged from 324 to 1198 FORT units, with a median value of 581 (494-754) FORT units. In univariate analysis, FORT values were positively related only to LVEF <40\% ( $\mathrm{p}=0.005)$, levels of CRP $(r=0.438$, $\mathrm{p}<0.001)$ and peak CK $(\mathrm{r}=0.274, \mathrm{p}=0.028)$. Multiple linear regression analysis showed that CRP ( $p=0.023)$, LVEF <40\% $(p<0.001)$ and the presence of diabetes $(\mathrm{p}=0.039)$ were independent predictors of serum FORT values. This statistical model can explain $45 \%$ of the variance in FORT values $\left(\mathrm{R}^{2}=0.45\right)$.

Conclusions: The FORT is a simple tool to assess circulating ROS in routine clinical practice. Oxidative conditions such as inflammation and diabetes are the major determinants of FORT values in patients with AMI.

Keywords: Reactive oxygen species, FORT, Myocardial infarction. 


\section{CONDENSED ABSTRACT}

The current work was designed to study the FORT, which is a new method to determine levels of circulating ROS, and to investigate the potential relationships between ROS and clinical or biological factors in male patients with acute myocardial infarction (AMI). FORT values ranged from 324 to 1198 FORT units, with a median value of 581 (494-754) FORT units. In univariate analysis, FORT values were influenced by LVEF <40\% ( $\mathrm{p}=0.005)$, levels of CRP ( $\mathrm{r}=0.438, \mathrm{p}<0.001)$ and peak CK $(\mathrm{r}=0.274, \mathrm{p}=0.028)$. Multiple linear regression analysis showed that CRP $(\mathrm{p}=0.023), \mathrm{LVEF}<40 \%(\mathrm{p}<0.001)$ and the presence of diabetes $(\mathrm{p}=0.039)$ were independent predictors of serum FORT levels $\left(\mathrm{R}^{2}=0.45\right)$. 


\section{ABBREVIATIONS LIST}

ACE: ANGIOTENSIN-CONVERTING ENZYME

AMI: ACUTE MYOCARDIAL INFARCTION

BMI: BODY MASS INDEX

CRP: C-REACTIVE PROTEIN

EPR: ELECTRON PARAMAGNETIC RESONANCE SPECTROSCOPY

FORT: FREE OXYGEN RADICALS TEST

GRACE: GLOBAL REGISTRY OF ACUTE CORONARY EVENT

HDL: HIGH DENSITY LIPOPROTEIN

LDL: LOW DENSITY LIPOPROTEIN

LVEF: LEFT VENTRICULAR EJECTION FRACTION

NON-STEMI: NON-ST SEGMENT ELEVATION MYOCARDIAL INFARCTION

NT-proBNP: n-terminal pro-b-type natriuretic peptide

ORAC: OXYGEN RADICAL ABSORBANCE CAPACITY

RICO : observatoiRe des Infarctus de Côte-d'Or

ROS: REACTIVE OXYGEN SPECIES

STEMI: ST SEGMENT ELEVATION MYOCARDIAL INFARCTION

WBC: WHITE BLOOD CELL COUNT 


\section{INTRODUCTION}

It has been suggested that reactive oxygen species (ROS) are involved in several pathological processes underlying cardiovascular diseases, particularly in the development of ischemiainduced myocardial reperfusion injury. When the balance between the cellular sources of ROS and the defence system is disturbed, ROS may react with cellular components like phospholipids and proteins. These reactions lead to lipid peroxidation and the oxidation of thiol groups resulting in the impaired function of both the cell membranes and various cellular proteins that influence responses to cardiac cell injury. Such responses include cell death, apoptosis and inflammation. ${ }^{\mathbf{1 , 2}}$ Therefore, understanding the role of oxidative stress in the development and initiation of atherothrombotic complications remains paramount. Direct measurement of ROS is very difficult because many are present in low concentrations and have short half-lives. In general, the action of ROS is assessed indirectly by studying the effects of substances involved in the production or elimination of these species. Methods to analyse these substances include chemical assays using direct chemiluminescence and either direct or spin-trap electron paramagnetic resonance spectroscopy (EPR). A number of reviews have described these methods, their logistical constraints, and their use in the measurement of ROS., ${ }^{\mathbf{3} 4}$ The Free Oxygen Radicals Test (FORT), (FORM ${ }^{\circledR}$, CR 2000, Callegari, Italy) was designed as a point-of-care system using freshly-collected heparinized whole blood. 5 Strong correlations between the FORT index and other indices of inflammation or oxidative stress have been reported. ${ }^{6,7}$ The current study was designed to test in our clinical conditions the potential relationships between the ROS and clinical or biological factors in male patients with acute myocardial infarction (AMI).

\section{METHODS}

\section{Patient population}

The participants in this study were recruited from the observatoiRe des Infarctus de Côte d'Or (RICO) survey, a French regional survey for AMI, the details of which have been previously published. ${ }^{\mathbf{8}}$ In the present study, consecutive male patients admitted to one of the aforementioned centres between $31^{\text {st }}$ December 2008 and $1^{\text {st }}$ March 2009 with acute myocardial infarction (ST-Elevation MI and Non-ST-Elevation MI) within 12 hours after symptom onset were included. MI was diagnosed according to European Society of Cardiology and American College of Cardiology criteria. ${ }^{\mathbf{P}}$ Patients under 18 years of age, women, patients with acute infection, acute inflammation, severe renal impairment, or with a prior chronic treatment (or for at least 7 days) with vitamin $\mathrm{C}$, steroids or non-steroid antiinflammatory drugs, and those with a CRP> $30 \mathrm{mg} / \mathrm{l}$ were excluded from the study. Women 
were excluded from the study because in women, FORT values vary considerably. ${ }^{\mathbf{1 0}}$ Sixtysix patients with AMI were recruited during the study period. This study complied with the Declaration of Helsinki, was approved by the ethics committee of the University Hospital of Dijon, and each patient gave written consent before participation.

\section{Data Collection}

The following data were collected; patients' characteristics: age, sex, and cardiovascular risk factors (history of or treated hypertension, know history of diabetes, treated hypercholesterolemia, body mass index $(\mathrm{BMI})\left(\right.$ weight $\left.(\mathrm{kg}) / \operatorname{height}\left(\mathrm{m}^{2}\right)\right)$, current smoker defined as person who reports active smoking of cigarettes within 3 months prior to this admission, prior MI. Hemodynamic parameters on admission (heart rate, systolic blood pressure) and the presence of clinical heart failure as defined by Killip class $>1$ were recorded. Patients were diagnosed with ST-segment elevation myocardial infarction (STEMI) when they had new or presumed new ST-segment elevation $>1 \mathrm{~mm}$ seen in any location or new left bundle branch block on the index or subsequent electrocardiogram. Anterior wall location was also recorded. Left ventricular ejection fraction (LVEF) was measured by echocardiography at $3 \pm 1$ days after admission using the Simpson method and dichotomized at $40 \%$ for more clinical relevance. ${ }^{11}$ The Global Registry of Acute Coronary Event (GRACE) risk score was calculated with the following admission variables: age, heart rate, serum creatinine, systolic blood pressure, Killip class, cardiac arrest, ST-segment deviation and cardiac markers (http://www.outcomes-umassmed.org/grace/acs_risk.cfm). ${ }^{\mathbf{1 2}}$ The duration of ischemia was the time between symptom onset and reperfusion. Chronic medications before admission (Aspirin, $B$-Blocker, ACE inhibitors, statin) and the number of percutaneous coronary interventions during the in-hospital period were recorded.

\section{Laboratory analysis}

At the time of admission, $10 \mathrm{~mL}$ of blood were drawn from the cubital vein into additive-free (serum) containers. Samples were allowed to clot at room temperature for 30 minutes and centrifuged at $3000 \mathrm{rpm}$ for 10 minutes at room temperature and then divided into aliquots. Samples were stored at $-20^{\circ} \mathrm{C}$ until the time of assay ( $<6$ Months). Median $\left(25^{\text {th }}-75^{\text {th }}\right)$ time from symptom onset to blood sampling was 193 (110-280) min.

ROS assay was determined using the free oxygen radical monitor (FORM) and kit. ${ }^{13}$ The FORM indirectly measures the concentration of hydroperoxides. Briefly, the apparatus uses transition metals to catalyze the formation of free radicals (alkoxyl and peroxyl radicals) from hydroperoxides in an acidic environment. The alkoxyl and peroxyl radicals extract an 
electron from the chromagen, N,N-diethyl-para-phenylendiamine. This leads to the formation of a coloured derivative that absorbs light at $505 \mathrm{~nm}$. This absorption is measured using the FORM analyzer. The ROS concentration is reported in FORT units, where 1 FORT unit corresponds to $0.26 \mathrm{mg} / \mathrm{L}$ of $\mathrm{H}_{2} \mathrm{O}_{2}$. This measurement was made in some 5,000 healthy volunteers to determine normal ranges (Incomat Medizinische Geräte manual, 2002). Because we aimed to determine the effect of storage, and the variability and reproducibility of the FORT in serum samples, FORT baseline values were obtained immediately, and the subsequent values after 1 day, 1 week and after one, two and six months of storage were analyzed in 6 patients. Peripheral white and neutrophil blood cell (WBC) counts were determined. Homocysteine concentrations were determined by chemiluminescence on an Immulite 2000 analyzer (Diagnostic Products Corporation, Los Angeles, USA). Plasma NTproBNP was determined by ELISA using Elecsys NT-proBNP sandwich immunoassay on Elecsys 2010 (Roche Diagnostics). CRP was measured on Dimension Xpand (Dade Behring) using immunonephelometry assay (analytical range $0.1-16 \mathrm{mg} / \mathrm{dL}$ ). Glucose concentrations (enzymatic method (glucose oxidase)) and creatinine levels were measured on a Vitros 950 analyzer (Ortho Clinical Diagnostics, Rochester, NY). Total cholesterol, high-density lipoprotein cholesterol (HDL-C) and triglyceride (TG) concentrations were measured on a Dimension analyzer (Dade Behring, Newark, NE). The level of low-density lipoprotein cholesterol (LDL-C) was calculated using the Friedewald formula. Peak plasma Creatine Kinase (CK) was assessed by sampling every $8 \mathrm{~h}$ during the first 2 days after admission and was expressed as \% of values 10 times higher than the upper limit of normal (ULN) (men: $170 \mathrm{UI} / \mathrm{L}$ and women: $135 \mathrm{IU} / \mathrm{L}$ ). The level of troponin Ic were measured using a technique based on colorimetry (Dimension analyzer, Roche). Glycated hemoglobin (HbA1c) was measured using a system of ion exchange HPLC. Baseline serum creatinine clearance was estimated using the Cockcroft-Gault formula. ${ }^{14}$

\section{Statistical Analysis}

The results are expressed as median values $\left(25^{\text {th }}-75^{\text {th }}\right.$ percentile $)$ for continuous variables or as percentages for qualitative variables. The normality of distribution for each variable was analysed by the Kolmogorov-Smirnov test. The Spearman or the Pearson test was used to perform the correlation between continuous variables and FORT values. For binary variables, the median FORT levels were compared with a Mann-Whitney test. A multiple linear regression analysis was performed to determine the independent factors associated with FORT levels. All variables listed in table 1 were tested in univariate analysis and were 
introduced into the multivariate model if the $p$ value $<0.20$. All analyses were performed using the Sigmastat Software (Jandel Inc.).

\section{RESULTS}

Study population; Among the 66 participants, median age was 60 (50-71). FORT values ranged from 324 to 1198 FORT units, with a median value of 581 (494-754) FORT units. Demographic characteristics, risk factors of the population, treatment on admission and hemodynamic parameters are presented in Table 1 . Seventeen percent of the patients were diabetic, and $20 \%$ were obese. The biological parameters are summarized in Table 2 . The correlation analysis between continuous variables and serum FORT concentrations are described in Tables 1 and 2. Age $(r=0.161, p=0.195)$, the presence of diabetes $(p=0.102)$, a history of MI ( $\mathrm{p}=0.181)$, LVEF <40\% ( $\mathrm{p}=0.005)$ and $\beta$-blockers before admission $(\mathrm{p}=0.053)$, ST-Elevation MI ( $\mathrm{p}=0.058)$, levels of CRP $(\mathrm{r}=0.438, \mathrm{p}<0.001)$, the neutrophil count $(\mathrm{r}=0.203$, $\mathrm{p}=0.107)$ and $\mathrm{CK}$ peak $(\mathrm{r}=0.274, \mathrm{p}=0.028)$ were related to FORT values in univariate analysis and introduced into a multiple linear regression analysis. CRP ( $\mathrm{p}=0.023), \mathrm{LVEF}<40 \%$ $(\mathrm{p}<0.001)$ and the presence of diabetes $(\mathrm{p}=0.039)$ were independent predictors of FORT values in the serum (Table 3$)\left(\mathrm{R}^{2}=0.45\right)$.

\section{DISCUSSION}

Our study gives valuable insights into the technical feasibility of the FORT in the context of acute MI. The analysis of factors affecting serum levels of FORT showed that CRP, impaired LVEF and the presence of diabetes were independent predictors of high FORT values. Despite the small size of the study population, these variables explain a significant proportion of the variance in FORT values.

The FORT: This simple tool that allows the measurement of circulating ROS may encourage the study of relationships between ROS concentrations and markers of CV diseases. By using a chromophore that is easily oxidized, the FORT provides a non-specific but sensitive and easy measurement of ROS in human samples. First described at the end of the 90s, the FORT is a variant of the $\mathrm{d}$-ROMs test ${ }^{\mathbf{1 5}}$ and uses similar methods. Both tests have been used to assess oxidative stress levels in humans. ${ }^{\mathbf{6}, 10,15-20}$ However, only a few studies are available in the setting of cardiovascular disease. Cesarone et al. reported FORT values of $404 \pm 42$ IU in patients with peripheral artery disease. ${ }^{15}$ To the best of our knowledge, there are no data 
about the use of this technique in patients with unstable coronary artery disease. Furthermore, our study is the first that specifically evaluates the relationship between FORT values and biological and clinical parameters in patients with AMI. Our work indicates that FORT values correlate with the presence of diabetes independently of other risk factors. Processes involving oxidative stress may be involved in coronary risk components that are increased in diabetics. ${ }^{21}$ Stranges et al. suggested, in a series of 1700 patients, that increased oxidative stress as measured by the ORAC test in individuals with clinical manifestations of atherosclerosis (AMI) was associated with abnormal glucose metabolism. In this case-control study, after adjustment for confounders, there was no significant difference in levels of oxidative stress measured into the 2 groups of patients (diabetics vs. non-diabetics). Interestingly, levels of oxidative stress were significantly higher only in the group of diabetic patients when compared with non-diabetics, irrespectively of sex or a history of MI. ${ }^{22}$ Our results also suggest a relationship between high FORT values and impaired LVEF. In experimental and clinical studies, impaired cardiac systolic function seems to be associated with an increase in oxidative stress. ${ }^{23-25}$

Oxidative stress and CRP: the relationship between the development of atherosclerosis, oxidative stress and inflammation is well documented thanks to various in-vivo studies. ${ }^{\mathbf{2 6}, 27}$ However, the relationship between CRP and oxidative stress remains poorly understood in AMI. In a series of obese patients without vascular disease, a strong relationship $(r=0.67)$ was found between CRP levels and a urinary metabolite of Oxidized LDL (8-iso PGF $2 \alpha){ }^{\mathbf{2 8}}$ In a population of 391 men, Hulth et al. reported a relationship between levels of oxidized LDL and intima-media thickness, the presence of carotid and/or femoral plaque and levels of CRP and TNF- $\alpha .{ }^{29}$ Abramson et al. ${ }^{6}$ in a series of 126 healthy adults reported an average FORT value of $136.8 \pm 348 \mathrm{IU}$, and showed a significant relationship between this marker and CRP values $(r=0.29)$. In the context of acute coronary syndromes, many studies have demonstrated the prognostic significance of markers of inflammation (CRP) and oxidative stress (MPO, malondialdehyde (MDA)-modified LDL), but no work has analyzed the relationship between the FORT index and markers of inflammation. Our results support the hypothesis of a close relationship between inflammation and this index, since we observed a strong correlation $(\mathrm{r}=0.438, \mathrm{p}<0.001)$ between CRP values measured on admission and FORT values. A trend towards a positive relationship between FORT values and the neutrophil count ( $\mathrm{r}=0.203, \mathrm{p}=0.107$ ) was also found, suggesting a link with the inflammatory process.

Study limitations: though our work focuses on a small number of patients, it took place in a context that reflects real world clinical practice. Given the lack of a control group (healthy 
subjects, stable coronary artery disease) and the fact that only men were involved, further work needs to be done on this topic. Finally, the clinical interest of the FORT as a prognostic marker remains to be investigated.

\section{CONCLUSIONS}

In conclusion, we found a significant positive association between oxidative stress, as measured by the FORT, and CRP in acute MI. Our work suggests the potential interest of the FORT method as a biomarker in patients with acute myocardial infarction. The relationship between this index and factors related to oxidative stress, particularly diabetes and CRP, strengthens the reliability of our results.

\section{ACKNOWLEDGEMENTS}

We wish to thank Anne Cécile Lagrost and Juliane Berchoud for research assistance and Philip Bastable for English assistance. This study received grants from the Conseil Régional de Bourgogne. 


\section{REFERENCES}

1. Ceconi C, Cargnoni A, Pasini E, Condorelli E, Curello S, Ferrari R. Evaluation of phospholipid peroxidation as malondialdehyde during myocardial ischemia and reperfusion injury. Am J Physiol 1991;260:H1057-H1061.

2. Hirasawa F, Kawarada Y, Sato M, Suzuki S, Terada K, Miura N, Fujii M, Kato K, Takizawa Y, Sugiyama T. The effect of silver administration on the biosynthesis and the molecular properties of rat ceruloplasmin. Biochim Biophys Acta 1997;1074:95100.

3. Vergely C, Maupoil V, Clermont G, Bril A, Rochette L. Identification and quantification of free radicals during myocardial ischemia and reperfusion using electron paramagnetic resonance spectroscopy. Arch Biochem Biophys. 2003; 15;420(2):209-16.

4. Tarpey MM, Am J Physiol Regul Integr Com Physiol 2004 / Zweier JL, Futura Publishing Company, Inc.;2003.

5. Curello S, Ceconi C, Cargnoni A, Cornacchiari A, Ferrari R, Albertini A. Improved procedure for determining glutathione in plasma as an index of myocardial oxidative stress. Clin Chem. 1987;33(8):1448-9.

6. Abramson JL, Hooper WC, Jones DP, Ashfaq S, Rhodes SD, Weintraub WS, Harrison DG, Quyyumi AA, Vaccarino V. Association between novel oxidative stress markers and C-reactive protein among adults without clinical coronary heart disease. Atherosclerosis. 2005;178(1):115-21.

7. Harris M, Davis W, Le N, Eggleston B, Austin G, Moussa M, Brown V. Free oxygen radicals in whole blood correlate strongly with high-sensitivity C-reactive protein. Journal of Clinical Lipidology (2007) 1, 593-598.

8. Zeller M, Steg PG, Ravisy J, Lorgis L, Laurent Y, Sicard P, Janin-Manificat L, Beer JC, Makki H, Lagrost AC, Rochette L, Cottin Y; RICO Survey Working Group. Relation between body mass index, waist circumference, and death after acute myocardial infarction. Circulation 2008;(29) 118(5):482-90.

9. Alpert JS, Thygesen K, Antman E, et al. (2000) Myocardial infarction redefined - a consensus document of The Joint European Society of Cardiology/American College of Cardiology Committee for the redefinition of myocardial infarction. J Am Coll Cardiol 2000; 36: 959-69.

10. Macciò A, Madeddu C, Massa D, Mudu MC, Lusso MR, Gramignano G, Serpe R, Melis GB, Mantovani G. Hemoglobin levels correlate with interleukin-6 levels in 
patients with advanced untreated epithelial ovarian cancer: role of inflammation in cancer-related anemia. Blood. 2005;106(1):362-7.

11. Pfeffer MA, Braunwald E, Moyé LA, et al. Effect of captopril on mortality and morbidity in patients with left ventricular dysfunction after myocardial infarction. Results of the survival and ventricular enlargement trial. The SAVE Investigators. N Engl J Med. 1992;327(10):669-77.

12. Fox KA, DabbousOH, Goldberg RJ, Pieper KS, Eagle KA, Van deWerf F, et al. Prediction of risk of death and myocardial infarction in the six months after presentation with acute coronary syndrome: prospective multinational observational study (GRACE). BMJ 2006;333:1091.

13. Alberti A, Bolognini L, Macciantelli D, et al. The radical cation of N,N,-diethyl-paraphenylendiamine: a possible indicator of oxidative stress in biological samples. Res Chem Intermed. 2000;26:253-267.

14. Cockcroft DW, Gault MH. Prediction of creatinine clearance from serum creatinine. Nephron 1976; 16:31-41.

15. Cesarone MR, Belcaro G, Carratelli M, Cornelli U, De Sanctis MT, Incandela L, Barsotti A, Terranova R, Nicolaides A. A simple test to monitor oxidative stress. Int Angiol. 1999;18(2):127-30.

16. Mantovani G, Madeddu C, Gramignano G, et al. Subcutaneous interleukin-2 in combination with medroxyprogesterone acetate and antioxidants in advanced cancer responders to previous chemotherapy: phase II study evaluating clinical, quality of life, and laboratory parameters. J Exp Ther Oncol 2003;3:205-19.

17. Gerardi G, Usberti M, Martini G, et al. Plasma total antioxidant capacity in hemodialyzed patients and its relationships to other biomarkers of oxidative stress and lipid peroxidation. Clin Chem Lab Med 2002;40:104-10.

18. Usberti M, Gerardi G, Bufano G, et al. Effects of erythropoietin and vitamin Emodified membrane on plasma oxidative stress markers and anemia of hemodialyzed patients. Am J Kidney Dis 2002;40:590-9.

19. Cornelli U, Terranova R, Luca S, Cornelli M, Alberti A. Bioavailability antioxidant activity of some food supplements in men and women using the D-Roms test as a marker of oxidative stress. J Nutr 2001;131:3208-11.

20. Pavlatou MG, Papastamataki M, Apostolakou F, Papassotiriou I, Tentolouris N. FORT and FORD: 2 simple and rapid assays in the evaluation of oxidative stress in patients with type 2 diabetes mellitus. Metabolism. 2009. 
21. Ceriello A, Motz E. Is oxidative stress the pathogenic mechanism underlying insulin resistance, diabetes, and cardiovascular disease? The common soil hypothesis revisited. Arterioscler Thromb Vasc Biol. 2004;24(5):816-23.

22. Stranges S, Dorn JM, Donahue RP, Browne RW, Freudenheim JL, Hovey KM, Trevisan M. Oxidation, type 2 diabetes, and coronary heart disease: a complex interaction: findings from a population-based study. Diabetes Care. 2008;31(9):18646.

23. Bouloumié A, Bauersachs J, Linz W, Schölkens BA, Wiemer G, Fleming I, Busse R. Endothelial dysfunction coincides with an enhanced nitric oxide synthase expression and superoxide anion production. Hypertension. 1997;30(4):934-41.

24. Varga E, Bodi A, Ferdinandy P, Droy-Lefaix MT, Blasig IE, Tosaki A. The protective effect of EGb 761 in isolated ischemic/reperfused rat hearts: a link between cardiac function and nitric oxide production. J Cardiovasc Pharmacol. 1999;34(5):711-7.

25. Carrasquedo F, Glanc M, Fraga CG. Tissue damage in acute myocardial infarction: selective protection by vitamin E. Free Radic Biol Med. 1999;26(11-12):1587-90.

26. Paul A, Ko KW, Li L, Yechoor V, McCrory MA, Szalai AJ, Chan L. C-reactive protein accelerates the progression of atherosclerosis in apolipoprotein E-deficient mice. Circulation. 2004;109(5):647-55.

27. Hansson GK, Libby P. The immune response in atherosclerosis: a double-edged sword. Nat Rev Immunol. 2006;6(7):508-19.

28. Davì G, Guagnano MT, Ciabattoni G, Basili S, Falco A, Marinopiccoli M, Nutini M, Sensi S, Patrono C. Platelet activation in obese women: role of inflammation and oxidant stress. JAMA. 2002;288(16):2008-14.

29. Hulthe J, Fagerberg B. Circulating oxidized LDL is associated with subclinical atherosclerosis development and inflammatory cytokines (AIR Study). Arterioscler Thromb Vasc Biol. 2002;22(7):1162-7. 
Table 1: Characteristics of the study population and relationship between levels of ROS measured by the FORT and various biological and clinical factors assessed on admission. ( $n=66)$. Results are expressed as (n (\%)) or median $\left(\left(25^{\text {th }}-75^{\text {th }}\right.\right.$ percentiles $) . *$ The $\mathrm{p}$ value expresses the correlation coefficient determined by the Spearman rank test for the continuous variables, or by the MannWhitney test for dichotomous variables.

\begin{tabular}{|c|c|c|c|c|}
\hline & $n=66$ & $\begin{array}{c}\text { Median FORT } \\
\left(25^{\text {th }}, 75^{\text {th }} \text { percentiles }\right)\end{array}$ & $\mathbf{r}$ & $\mathbf{p}^{*}$ \\
\hline Age (years) & $60(50-71)$ & $*$ & 0.161 & 0.195 \\
\hline BMI $\left(\mathrm{kg} / \mathrm{m}^{2}\right)$ & $26(23-29)$ & * & -0.073 & 0.559 \\
\hline Heart rate (beat/min) & $76(64-90)$ & $*$ & 0.117 & 0.350 \\
\hline Systolic Blood Pressure (mmHg) & $137(120-163)$ & $*$ & -0.024 & 0.853 \\
\hline GRACE Risk Score & $120(93-148)$ & $*$ & 0.114 & 0.363 \\
\hline Duration of ischemia (min) & $183(110-280)$ & $*$ & -0.113 & 0.363 \\
\hline $\operatorname{LVEF}(\%)$ & $59(50-60)$ & $*$ & -0.206 & 0.096 \\
\hline $\begin{array}{l}\text { Hypertension } \\
\text { Yes }(\mathrm{n}=31) \\
\text { No }(\mathrm{n}=35)\end{array}$ & $31(47 \%)$ & $\begin{array}{l}567(494-802) \\
582(506-741)\end{array}$ & & 0.913 \\
\hline $\begin{array}{l}\text { Diabetes } \\
\text { Yes }(\mathrm{n}=11) \\
\text { No }(\mathrm{n}=55)\end{array}$ & $11(17 \%)$ & $\begin{array}{l}720(558-933) \\
576(494-741)\end{array}$ & & 0.102 \\
\hline Dyslipidemia & $29(44 \%)$ & & & \\
\hline $\begin{array}{l}\text { Yes }(n=29) \\
\text { No }(n=37)\end{array}$ & & $\begin{array}{l}576(488-748) \\
585(501-764)\end{array}$ & & 0.727 \\
\hline Prior MI & $6(9 \%)$ & & & \\
\hline $\begin{array}{l}\text { Yes }(n=6) \\
\text { No }(n=60)\end{array}$ & & $\begin{array}{l}517(376-638) \\
583(499-760)\end{array}$ & & 0.181 \\
\hline Current smoker & $35(53 \%)$ & & & \\
\hline $\begin{array}{l}\text { Yes }(\mathrm{n}=35) \\
\text { No }(\mathrm{n}=31)\end{array}$ & & $\begin{array}{l}585(496-760) \\
580(494-747)\end{array}$ & & 0.928 \\
\hline Obesity & $13(19 \%)$ & & & \\
\hline $\begin{array}{l}\text { Yes }(n=13) \\
\text { No }(n=53)\end{array}$ & & $\begin{array}{l}640(492-764) \\
580(494-746)\end{array}$ & & 0.723 \\
\hline LVEF $<40 \%$ & $5(8 \%)$ & & & \\
\hline $\begin{array}{l}\text { Yes }(\mathrm{n}=5) \\
\text { No }(\mathrm{n}=61)\end{array}$ & & $\begin{array}{l}810(796-940) \\
576(494-722)\end{array}$ & & 0.005 \\
\hline Aspirin & $6(9 \%)$ & & & \\
\hline $\begin{array}{l}\text { Yes }(n=6) \\
\text { No }(n=60)\end{array}$ & & $\begin{array}{l}540(494-700) \\
581(496-762)\end{array}$ & & 0.662 \\
\hline B-Blocker & $8(12 \%)$ & & & \\
\hline $\begin{array}{l}\text { Yes }(\mathrm{n}=8) \\
\text { No }(\mathrm{n}=58)\end{array}$ & & $\begin{array}{l}494(415-620) \\
587(514-764)\end{array}$ & & 0.053 \\
\hline ACE inhibitor & $15(21 \%)$ & & & \\
\hline Yes $(\mathrm{n}=15)$ & & $558(494-629)$ & & 0.277 \\
\hline No $(\mathrm{n}=51)$ & & $589(506-764)$ & & \\
\hline Statins & $11(17 \%)$ & & & \\
\hline Yes $(n=11)$ & & $638(505-837)$ & & 0.434 \\
\hline No $(\mathrm{n}=55)$ & & $576(494-742)$ & & \\
\hline Killip >1 on admission & $6(9 \%)$ & & & \\
\hline Yes $(n=6)$ & & $760(638-1062)$ & & 0.034 \\
\hline No $(n=60)$ & & $576(494-737)$ & & \\
\hline ST-Elevation MI & $33(50 \%)$ & & & \\
\hline Yes $(\mathrm{n}=33)$ & & $596(566-768)$ & & 0.058 \\
\hline No $(n=33)$ & & $527(478-746)$ & & \\
\hline Anterior wall location & $17(26 \%)$ & & & \\
\hline Yes $(\mathrm{n}=17)$ & & $596(517-821)$ & & 0.270 \\
\hline No $(n=49)$ & & $566(494-741)$ & & \\
\hline
\end{tabular}


Table 2: Biological data of the study population and relationship with ROS levels measured by the FORT determined by the Spearman rank test $(n=66)$. Results are expressed as median $\left(\left(25^{\text {th }}-75^{\text {th }}\right.\right.$ percentiles $)$.

\begin{tabular}{lccc}
\hline & Median value & \multicolumn{2}{c}{ Total (n=66) } \\
& & $\mathbf{r}$ & $\mathbf{p}$ \\
\hline CRP (mg/l) & $3.7(2.1-8)$ & 0.438 & $<0.001$ \\
Peak Creatinine kinase (UI/l) & $637(222-1457)$ & 0.274 & 0.028 \\
Neutrophil Count (10 ${ }^{9}$ cells/L) & $3.1(1.2-8.4)$ & 0.203 & 0.107 \\
Admission Glucose (mmol/l) & $6.29(5.61-9.44)$ & 0.180 & 0.148 \\
WBC (10 ${ }^{9}$ cells/L) & $5.9(3.4-12.2)$ & 0.138 & 0.275 \\
Homocysteine (mg/l) & $13(10-18)$ & 0.089 & 0.537 \\
HbA1c (\%) & $5.7(5.5-6.1)$ & 0.072 & 0.600 \\
NT-proBNP (pg/ml) & $311(112-1023)$ & 0.072 & 0.571 \\
HDL Cholesterol (mg/dl) & $0.40(0.37-0.47)$ & 0.047 & 0.721 \\
LDL Cholesterol (mg/dl) & $1.29(1.06-1.51)$ & -0.036 & 0.789 \\
Total Cholesterol (mg/dl) & $2.05(1.7-2.26)$ & -0.108 & 0.411 \\
Creatinine clearance (ml/min) & $86(64-107)$ & -0.154 & 0.216 \\
Triglycerides (mg/dl) & $1.01(0.56-1.61)$ & -0.232 & 0.367 \\
\hline BNP : n-terminal pro-b-type natriuretic & peptide, CRP : C-Reactive Protein, LDL-C, & \\
Hensity lipoprotein, HDL-C, high density lipoprotein, WBC : white blood cell count.
\end{tabular}


Table 3: Determinants of the FORT value by multiple linear regression $(n=66)$.

\begin{tabular}{lcc}
\hline & \multicolumn{2}{c}{ Total Population } \\
& Coefficient $\boldsymbol{\beta}$ & $\mathbf{p}$ \\
\hline LVEF < 40\% & +0.421 & $<0.001$ \\
CRP & +0.265 & 0.023 \\
Diabetes & +0.232 & 0.039 \\
Peak Creatinine kinase & +0.172 & 0.177 \\
Age & +0.133 & 0.301 \\
Neutrophil Count & +0.071 & 0.589 \\
ST-Elevation MI & -0.033 & 0.785 \\
B-Blocker on admission & -0.134 & 0.265 \\
Prior MI $\quad-0.197$ & 0.119 \\
\hline \multicolumn{1}{c}{$\mathrm{R}^{2}$} & 0.45 & $*$ \\
\hline
\end{tabular}

LVEF: Left Ventricular Ejection Fraction; CRP: C-Reactive protein; STEMI: ST-Elevation Myocardial Infarction.

Figure 1: Direct measurement of $\mathrm{H}_{2} \mathrm{O}_{2}$ with the FORT system.

Figure 2: Linearity of the Direct measurement of $\mathrm{H}_{2} \mathrm{O}_{2}$ with the FORT system.

Figure 3: Analysis of the correlation between FORT values and CRP. $(n=66)$. 